\title{
Transatlantica
}

Revue d'études américaines. American Studies Journal

\section{Microhistory, Biography, Fiction}

The Politics of Narrating the Lives of People under Slavery

\section{Sue Peabody}

\section{OpenEdition}

\section{Journals}

Édition électronique

URL : https://journals.openedition.org/transatlantica/6184

DOI : 10.4000/transatlantica.6184

ISSN : 1765-2766

Éditeur

Association française d'Etudes Américaines (AFEA)

Référence électronique

Sue Peabody, « Microhistory, Biography, Fiction », Transatlantica [En ligne], 2 | 2012, mis en ligne le 25 mai 2013, consulté le 06 avril 2023. URL : http://journals.openedition.org/transatlantica/6184 ; DOI : https://doi.org/10.4000/transatlantica.6184

Ce document a été généré automatiquement le 6 avril 2023.

\section{cc) (†) $\odot$}

Creative Commons - Attribution - Pas d'Utilisation Commerciale - Pas de Modification 4.0 International - CC BY-NC-ND 4.0

https://creativecommons.org/licenses/by-nc-nd/4.0/ 


\title{
Microhistory, Biography, Fiction
}

The Politics of Narrating the Lives of People under Slavery

\author{
Sue Peabody
}

1 We live in an extraordinarily rich time for the study of slavery and emancipation. ${ }^{1}$ In the last fifty years, literally thousands of books on the history of slavery have been published, many of these appearing in the last decade. One narrative strategy, increasingly embraced by historians of a range of periods and settings, is the biography, telling life stories of particular people in slavery and upon emancipation. Rather than writing about a mass of mostly anonymous individuals and the institutions that framed their lives, these historians have chosen to narrate how bondage was experienced and interpreted by selected individuals or communities. The best of these new works cast light on the wider social, ideological and political context of their historical times.

2 Biographies of slaves are increasingly common in United States historiography, but very rare for the history of France's slave colonies. ${ }^{2}$ Several recent and forthcoming biographical projects narrate the lives of slaves and freed people who, at some point, transited or lived within the French empire. Perhaps the most successful of these is Annette Gordon-Reed's Pulitzer-prize-winning The Hemingses of Monticello, which recovers the hidden story, over multiple generations, of the family enslaved to Thomas Jefferson, including new insights into the residence of Sally and James Hemings in Paris. Pamela Scully and Clifton Crais's Sara Baartman and the Hottentot Venus is a thoughtful and nuanced biographical study of a black woman-who may or may not have been a slave-displayed as an icon of exoticism in England and France in the early nineteenth century. Rebecca Scott, Jean Hébrard and Martha Jones, are working collectively and individually on several biographical projects concerning generations of families in slavery and freedom, with connections to Saint Domingue and Haiti. ${ }^{3}$

3 More generally, however, as acknowledged by many authors in a recent issue of the American Historical Review, many scholarly historians have regarded biography as trivial, uncritical, or lightweight. ${ }^{4}$ They point to such shortcomings of biography as the arbitrariness and narrowness of its focus on a single life and its tendency to neglect social and political context, to treat documentary evidence in a superficial way, and to 
give a heroic cast to its subject. Many of these shortcomings can be linked to the general American audience for biography, which is deemed to find the critical apparatus and distanced stance that historians favor hopelessly tedious and dry. ${ }^{5}$

The politics of narration, however, make the telling of a life story different, according to the position of the subject of that study. That is, a biography of Jefferson, however told, implicitly foregrounds the experiences of this elite individual, as opposed to biographies of Sally or James Hemings, even when discussing the same episodes and using the same evidentiary sources. The authors and editors of nineteenth-century slave narratives knew this. Abolitionists, beginning with Equiano and Cugoano in the eighteenth century, and continuing through the nineteenth century, appropriated the Calvinist-inspired genre of the captivity narrative to tell the story of enslavement and liberation of particular slaves, and circulated to Atlantic audiences hundreds of these stories in thousands of copies. ${ }^{6}$ The plot of liberation is so central to these stories that Paul Lovejoy has recently proposed that the term "slave narrative" be replaced with the phrase "freedom narrative" (Lovejoy, 2011, 91-107). However, this genre only flourished in the English-speaking Atlantic world; no French "slave narratives"-save the captivity narratives of Frenchmen held as slaves in the Maghreb-were published in the eighteenth or nineteenth centuries. However, novelists-generally privileged whites (often women)-imagined the subjectivity of enslaved people in novels like Oroonoko, Uncle Tom's Cabin, Ourika, Paul et Virginie, Huckleberry Finn, to call attention to the injustice of slavery and racial injustice.

5 In the 1970s and 1980s some historians invented the genre of "microhistory" as a means of recovering the "lost histories" of early modern European peasants by relying on the rare surviving records of the "exceptionale normale," those cases that reflected the norms of peasant experience but happened to be collected and preserved in the historical records. While some social historians, beginning in the 1960s, had succeeded in using serial records generated by the church and state-such as tax, birth, marriage, conscription, commodity and death registers-to recover the macrohistorical forces affecting demography, migration, and economies, the statistical methods that were required for this work tended to reduce the peasants to mere products of historical forces, excluding the possibility that they may rather have been agents and interpreters of their own lives. Ginzburg, Le Roy Ladurie, Ruggiero, Davis, Darnton, to name only the most famous of these practitioners, engaged in a self-consciously political resurrection of the perspective of oppressed people-peasants, heretics, women-in an effort to give the subjectivity of these people the kind of attention previously given only to elites. These historians were especially drawn to legal records, because these records often included detailed transcriptions (however mediated) of the oral testimony of illiterate people. ${ }^{8}$ It is no surprise, then, that historians of imperialism and slavery have been drawn to similar sources and narrative enterprises, to tell history "from the bottom up."

6 In 2008, I began to research and write the life story of Furcy, a man who pursued his legal case for freedom in French and British courts between 1817 and 1843. The story of his life and that of his family is full of intrinsic dramatic interest; almost-as they saymade for the movies. Almost immediately I recognized the potential for rendering the story as a novel and began to experiment with a fictive voice. Indeed, at about the same time, the French journalist Mohammed Aïssaoui, began researching and writing a novel based on Furcy's life, which has since been published and produced as a play. ${ }^{9}$ 
Ultimately, however, I decided that non-fiction historical writing was the better, if more difficult, narrative strategy, at least partly because telling a "true" story was ultimately more compelling than the imaginative embellishments permitted by fiction. Yet, even within non-fiction, it was difficult to decide whether to call the project a "biography" or a "microhistory." "Biography" suggests an important personage (which is arguably true in Furcy's case, since the legal decision in his case re-affirmed France's Free Soil principle and excluded racial arguments for freedom in French law) while "microhistory" emphasizes the unimportant nature of the protagonist-an "everyman" whose experience sheds light on the life of the commoner. The challenge of narrating Furcy's life led me to ponder deeper questions about genre and representation.

In this essay, I consider the implications of rendering Furcy's story into three competing genres: fiction, biography and microhistory. I argue that while the novel offers interesting narrative possibilities-including the freedom to invent where evidence is missing, the capacity to imagine the point of view of historical characters, and a potentially wider audience than scholarly historical writing-historical fiction also inherently presents certain dangers and distortions. In seeking to connect contemporary readers with the strangeness of the past, fiction writers inevitably distort their representation of the past by seamlessly pressing "presentist" interpretations or perspectives anachronistically onto the past. ${ }^{10}$ The popular biography, while more constrained than fiction, also shares many narrative strategies of the novel and has the potential to reach a wider audience than the microhistory but runs many of the same risks of anachronism and homogenization. The microhistory's great strength is the way it joins the elemental power of a good story-telling (characters, plot, description) with a postmodern commitment to revealing the architecture of historical research and exposition. The microhistory works on at least three levels: 1) it recovers the lost stories of individuals' struggles; 2) it situates them in the wider macrohistorical context of their times; and 3) it illuminates the relations of power and conventions of representation to show why subalterns' stories are so very hard to reconstruct in the first place.

\section{Furcy}

9 The basic narrative of Furcy's life, beginning with his mother's childhood as slave in India, through his successive legal efforts to attain free status in at least three different jurisdictions, and culminating with General Emancipation throughout French territories in 1848, transits half the globe and almost century. My sources are voluminous, including three thick dossiers comprising hundreds of pages collected by a magistrate who championed Furcy's freedom early on, only to be driven out of the colony for interfering with the plantocratic regime, and eight letters signed by Furcy. The judge's papers are complemented by colonial parish and census records, court documents, two lawyers' pamphlets, ship manifests, newspapers, and a surprising number of "needles in the haystack" culled from primary and secondary sources, now easily located via keyword search online. These fragments are contextualized by a rich historiography of slavery and the slave trade in the Indian Ocean world, which allows us to see the macrohistorical changes of the Indian Ocean world from the point of view of Furcy and his family. ${ }^{11}$ 

Chandernagor, near British Bengal, in northeastern India, around 1759, and christened Madeleine, the slave of a French nun. When Madeleine was about thirteen, the nun brought her to the French port city of Lorient, where she neglected to register Madeleine as her slave. Technically, this oversight should have either rendered Madeleine free, following France's Free Soil Principle, or prompted the royal government to confiscate Madeleine and return her to the colonies for resale to new masters. ${ }^{12}$ Instead, the nun, upon entering a convent, transferred Madeleine to a family of planters, the Routiers, under the condition that they return Madeleine to the Indies and free her there. This may have been a clandestine (because illegal) sale or simply a convenient means of "disposing" of Madeleine, whose services were no longer needed by the nun. ${ }^{13}$

11 A fourteen-year-old Madeleine then accompanied the pregnant Madame Routier on the long ocean voyage to Ile Bourbon, and attended at the birth "en mer" of her mistress's fourth child, a daughter named Eugénie. Despite the prior agreement, in Ile Bourbon, Madeleine remained the Routiers' slave. She gave birth to three children, all born out of wedlock: Maurice, Constance, and Furcy. We know almost nothing about Maurice, but Constance was, very unusually, transferred to a white colonist and freed by him while still a baby; circumstantial evidence suggests that one of the Routier men was her father. Constance would remain an important figure in the life of her younger brother Furcy, whose father-also probably a white man-is unknown. colonial administrators and obtained official papers of manumission, freeing the thirtyyear-old Madeleine (but not her sons, Maurice or Furcy, the latter still a nursing toddler). According to later testimony by Constance and Furcy, however, Madame Routier neglected to tell Madeleine that she was free. Madeleine remained with the widow Routier; her son, Furcy, received special attention and education, learning to read and write, and eventually becoming the chief household manager, or maitre d'hôtel.

The revolutionary years, so convulsive in the French Atlantic world, were born with relative tranquility in the Indian Ocean colonies. The Mascarenes, including Ile Bourbon and neighboring Ile de France, were strategically important to both France and England as way stations to the eastern posts of their respective empires and as slave-trading hubs. The same divisions between republican and royalist factions embroiled the two Indian Ocean island colonies, which, like the Caribbean colonies, held more than $80 \%$ of their respective populations in slavery. Rumors of imminent liberation circulated amongst slaves and a curate was denounced for having abolitionist views in Ile Bourbon, renamed Réunion by Parisian revolutionaries in 1793 (Wanquet, 1980-1984, 1, 396-406; Wanquet, 1998, 11).

14 Meanwhile, the widow Routier busied herself with arranging marriages for three of her four adult children. In 1790 the two eldest sons, Augustin and Cyrille, married two sisters, Anne Adélaïde and Thérèse Agnès Rathier-Duvergé, daughters of the Commissaire des colonies and born in Pondichéry (Ricquebourg, 1983, 3, 2364-65 and 3, 2590). Eugénie Routier, the daughter whose shipboard birth Madeleine had attended, now age 21, was betrothed and married to a businessman from Ile de France, Joseph Lory, in 1794; they set up household in Ile Bourbon, now renamed La Réunion. A scant nine months later she gave birth to their first child, a daughter (Ricquebourg, 1983, 2, 1753). ${ }^{14}$ Yet these weddings may not have been such happy events for Madeleine and 
her children; it seems likely that these occasions forced the separation of Madeleine from her two sons as Maurice (approximately 13) was transferred to Cyrille and Furcy (who would have been eight years old) to Eugénie, probably as wedding gifts. Constance continued to live with her mother and the widow Routier and two other servants, now resident in the city of Saint-Denis.

Unlike Saint-Domingue, Guadeloupe and Guiana, where formal declarations of the abolition of slavery were instituted by representatives of the republican government, the colonial regimes of La Réunion and Ile de France managed to resist the imposition of the Parisian emancipation act of 16 pluviôse, An II (4 February 1794). Emissaries from the Convention bearing the third constitution and formal notice of emancipation, were forcibly rejected by the Colonial Assembly of Ile de France and deported back to France by way of the Philippines, while a representative was quickly dispatched to Paris to justify the colony's resistance to the abolition decree (Wanquet, 1998). The emissaries never reached Ile Bourbon, where the government and planters increased police vigilance-arresting, prosecuting and exiling slaves suspected of resistance and plotting revolt (Wanquet, 1980-1984, 2, 347-56). ${ }^{15}$ Napoleon officially attempted to restore slavery throughout the French empire in 1802, ultimately prompting Haitian independence, though in practice slavery had never disappeared in the Mascarenes. Réunion was renamed once more, as Ile Bonaparte, in honor of the emperor in 1806.

The first decade of the nineteenth century was a critical turning point in the history of slave emancipation. English and American governments abolished the slave trade in 1807 and 1808 respectively. In 1808, Napoleon installed his brother on the Spanish throne. One year later, Cuba expelled the exiles of Saint-Domingue, thousands of whom relocated with the people they held as slaves (in violation of US federal law) to New Orleans.

17 News of such affairs probably reached the ears of Madeleine and Furcy only as distant rumblings. Of much more immediate importance was the death of Madame Routier, on 4 October 1808. It was shortly thereafter, probably upon the reading of the will, that Madeleine first learned of her formal manumission that was promulgated-but never put into practice-nineteen years earlier, in 1789. We can only imagine the amazement and outrage she must have felt upon learning that: 1) she was free; 2) she had been unlawfully enslaved by the Routier family for nearly two decades; and 3) she was legally owed nineteen years of back wages, a significant sum of money, worth three or four skilled adult male slaves.

Eugénie's husband, Joseph Lory, apparently the executor of the Routier estate, entered into negotiations with Madeleine. If she would sign a receipt for the back wages, he would agree to manumit her son, Furcy-according to later, varying accounts-in a year or two, or upon Lory's return from travels to metropolitan France. Madeleine agreed to sign the receipt but Lory evaded any written agreement to manumit Furcy. Madeleine died, allegedly of grief, several years after realizing that she had lost everything.

Furcy remained in the Lory household for another five years; in 1817 a change in the colonial judicial regime created an opportunity for him to challenge his enslavement. New appointments in the French overseas ministry signaled important changes in metropolitan policy towards slavery and especially free people of color in the French empire and the wider Atlantic world. ${ }^{16}$ In July 1817, a new procureur général, a senior magistrate charged, among other things, with representing the interests of the poor, arrived in Ile Bourbon as the new representative of the king's justice in the colony. ${ }^{17}$ 
Furcy, now thirty, made his move, declaring himself a free man and embarking on a legal challenge of his enslavement to Lory. His sister Constance came to testify on his behalf and was arrested by local colonial administrators.

The legal officials who championed Furcy's cause, including a liberal creole colonist (who may have had an African ancestor) ${ }^{18}$ and the new metropolitan judge, crafted two primary arguments to support his case: a racial argument (all Indians were free) and a Free Soil argument (any slave who set foot on metropolitan soil became free). By both counts, they argued, Madeleine should have been a free woman at the time that she gave birth to Furcy. However, in the end, local powers proved stronger than the king's justice at a distance; Furcy's advocates were accused of fomenting slave revolt. The creole colonist was summarily removed from his post and banished to his plantation while the magistrate transferred his post to a local substitute and fled to the metropole. Furcy lost his freedom suit twice, at the court of first instance and upon appeal.

21 After spending a year in the Bourbon jail, Furcy was removed to Lory's sister's property in nearby Mauritius, populated by French colonists but now under British rule. Furcy lived there through the 1820 s, occasionally writing letters to the French judge who had championed his cause, who was variously stationed in Corsica, Paris and Poitiers. In one letter, Furcy asserted that he was "born a French colonist and [...] son of a Frenchman by birth" the only explicit reference I have found to a white father (which, nevertheless, seems quite plausible). ${ }^{19}$ It is no accident, I think, that Furcy's claim to Frenchness coincided with a wide, international movement by sons of mixed race ancestry throughout the French empire, from the Canadian métis, to the Antillean gens de couleur, the most famous of whom is Cyrille Bissette. ${ }^{20}$ In France's colonies and former colonies, these sons and grandsons of French colonists and indigenous or enslaved women would protest their second-class status and mistreatment on the basis of racial exclusion.

Finally, in 1826, as England sent its Commission on Inquiry to investigate slave abuse in Mauritius, Furcy protested his enslavement once more on the grounds that he had been illegally smuggled into the colony and never properly censused there, eventually negotiating his freedom from the Lory family. Furcy then remained in Mauritius, now a free man of color, amassing "a small fortune" as a confiseur, or candy-maker (Bissette, 1844, 58).

In the 1830s, Furcy traveled to Paris, his freedom papers hidden in his shoe, seeking to overturn the 1818 decision that made him a slave within French jurisdiction. Furcy's appeal probably prompted the French legislature to pass the Ordinance of 29 April 1836, which formally rendered France's Free Soil principle into positive law for the first time since the Revolution. ${ }^{21}$ Nevertheless, it would be another seven years, following the natural death of Joseph Lory, before France's highest court of appeal, the Cour royale de Paris, recognized Furcy "né libre" and upheld the Free Soil principle as an essential fundament of French law. As near as we can tell, the fifty-six year old Furcy then returned to Ile Bourbon, to be with his family. Five years later, during the Revolution of 1848 , the French government abolished slavery definitively throughout its empire. 


\section{Genre: Biography, Microhistory, Fiction}

24 Furcy's story is compelling on many levels: personal, legal, and historical. It is also unusually well documented over a long period of time, especially for someone of low social standing, including a slave. This is due to a number of factors. First, the French colonial state in eighteenth and nineteenth-century Ile Bourbon employed a high degree of surveillance over its population, including census, parish and passenger records, that allow us to document Furcy's location and social constellation at frequent intervals (though these records tell us relatively little about how Furcy experienced these conditions). Secondly, Furcy's ceaseless efforts to litigate for his freedom over two and a half decades (1817-1843) created a voluminous paper trail that was collected and saved by both state institutions and private individuals..$^{22}$ These include depositions by Furcy and his sister Constance that narrate events from their own point of view to sympathetic listeners: the legal professionals who attempted to get Furcy freed in court. Thirdly, it appears that Furcy learned to read and write-certainly there are a handful of letters from him that probably bear his signature; these offer rare glimpses into his thoughts and aspirations at key moments. ${ }^{23}$

The challenges posed to narrating, as opposed to merely researching, Furcy's life, however, have also been numerous. As with any microhistory, most of the documentation is produced by people and institutions that are less interested in the perspectives of the slave than of the institutions they represent. It is the intersection of Furcy's life with institutions like the church and the judiciary (and later, the press) that produces evidence about his life. Between this documentation, there are wide gaps of silence, which the historian must seek to fill carefully with informed speculation. ${ }^{24}$ There is a great danger of reading one's presentist assumptions into the past. Moreover, there is the question of audience-Furcy's story has the potential to reach a wide readership, including the general public, and to engage these readers in an informed new understanding of the history of slavery and abolition. However, in seeking the accuracy and nuance afforded by scholarly techniques of analysis (including the conditional speculation of the microhistory), we run the risk of losing the interest of general readers who simply want a good story. Let me begin my analysis of historical narration by laying out what I see as the essential features of each genre: biography, microhistory and fiction.

Biography, as some would have it, is a very old genre, with precursors in the ancient world in the form of epic celebrations of warriors and kings, and medieval innovations in the hagiography of saints. ${ }^{25}$ It takes as its structure or "plot," the life of an individual, from birth to death, and is often celebratory. Until the mid-twentieth century, the subjects of biographies were typically elites or exceptional, exemplary people whose lives were cast in the heroic mode.

Microhistory, which emerged first in Italy and was later adopted by French Annalistes and their emulators in the United States, was a self-consciously political attempt to move beyond the limitations of previous social history trends, like cliometric history, to recover the lived experience of the underclass-the "people without history." While cliometric historians, who typically analyzed vast arrays of serial data (e.g. fertility, morbidity and migration), shared the microhistorians' goal of writing a "total" history of the popular classes, they nevertheless tended to portray the downtrodden as the subjects of external forces: economics, disease, politics or religion. By casting peasants 
as the subjects of powerful narratives, the purveyors of microhistory deliberately cast these people as heroic resistors to official power. ${ }^{26}$

Another defining characteristic of microhistory, besides its choice of subject, is a postmodern tendency to explicitly signal the elements of historical interpretation, especially when historical evidence is scant or contradictory. I like to compare microhistory to the architecture of the Centre Pompidou, which deliberately exposes its ductworks and stairwells, rather than secreting away the elements of construction behind walls. Natalie Zemon Davis, for example, famously strung together the hints that her heroine Bertrande de Rols was both inclined toward Protestantism and "in" on the imposture of her husband, the "new" Martin Guerre (Davis, 1983, 44, 47-50, 60). Her critics were furious that she would offer these interpretations on scant documentary evidence but it was Davis's academic honesty and the explicit textual markings of these narrative bridges that also made her vulnerable to attack. Davis, like other practitioners of microhistory, is committed to foregrounding what we know and how we know it, as well as marking what we do not know. By contrast, biographersespecially those writing for the general public-are more inclined to paper over these ambiguities in a clear, declarative narrative that does not force readers to struggle with the ambiguities of the historical record.

It may seem odd to include historical fiction as a narrative option for historians. It is rare that a professional historian steps outside of the formal narrative structures of argument and evidence to produce a novel or short story based in their area of expertise. Whether this is due to training, temperament, skill or the threat to professional reputation, we have very few examples of academic historians writing historical fiction. We "professionals" write the "facts" (and offer our analysis) and we leave it to the novelists to employ the arsenal of narrative tricks that constitute the essence of modernist fiction: character development, imagination, internal monologue, dialogue, variant point of view, and suspense. Yet, it is obvious that, of the three genres, historical fiction (in its sophisticated as well as popular forms) reaches the widest audience, and-through film adaptation-has the most potential to reach even further. ${ }^{27}$ Arguably, if one seeks to reframe the general public's understanding of the history of slavery so as to advance the rights of slaves' descendants in the present, fiction may have the most revolutionary potential to change the public's knowledge of the past and therefore present culture and structures of power.

\section{Characters and Plot}

30 Several decades ago, Hayden White provocatively challenged the objectivist tradition in historiography by showing how classic works of history rely upon many of the same poetic conventions as fictive writing: plot and character, point of view and mode (White, 1973). Likewise, it may be useful to consider how biography, microhistory and fiction, each typically represent these key elements of historical narrative.

To return to Furcy, my first narrative decision concerns the protagonist of my study. Should Furcy be the "hero" of my story, as I have already cast him in the preceding narrative? Certainly Furcy has left the greatest documentary trail-including those sheaves compiled by his sympathetic magistrate. So, too, Furcy's story can be easily cast as a story of heroic triumph over adversity-a decades' long struggle to be declared free-and the irony of the court's ultimate ruling that he was, indeed, "born free." 

women of his life, Madeleine and his sister Constance, to mere "supporting cast," thereby playing into the gender inequalities and attitudes that framed both the circumstances of their lives and prevailing patriarchal attitudes of French culture? Were I to cast Madeleine as the "hero," or primary subject of my study, I would certainly find considerably less archival evidence with which to recover her perspective, due to her earlier lifespan (1759-1812) and her illiteracy; moreover, Madeleine's inability to afford a legal challenge in the courts without a public prosecutor (all of which are compounded by gender relations during her lifetime), have led to enormous factual gaps and ambiguities in her life story. Madeleine's relative invisibility as a woman would push me to one of two genres: the microhistory, with its hallmark hypotheticals and "may have been," which delight some historians but trip up many a general reader ${ }^{28}$-or fiction, which permits invention to create her subjectivity, but runs a greater risk of imposing contemporary assumptions on historical subjects.

Selecting a protagonist has immediate implications for the plot. Madeleine's wanderings from Chandernagor, to Lorient, to Ile Bourbon might be told as a picaresque travelogue or, more likely, a tragedy, ending with Lory's betrayal and her death in despair. Furcy's storyline is more ambiguous. His mother's treatment at the hands of the Routiers and Lory are the grounds of his determined resistance. But where does his story end? With his personal triumph before the Cour royale de Paris? His probable return to his family in Ile Bourbon? The general emancipation of Réunion in 1848 ? Or should the narrative foreground the irony of a man who struggled all his life to achieve official recognition of his personal freedom from the Routier/Lory family, only to have the entire institution of slavery, and presumably his hard-won legal distinction as a free man, abolished shortly thereafter?

A decade ago, Rebecca Scott, Thomas Holt and Fred Cooper urged historians to go "beyond slavery," in their analysis of labor and the history of race relations (Cooper, Holt, and Scott, 2000). The decades following formal legal abolition were critical, they argued, in understanding the contemporary positions of laboring classes in Cuba, Jamaica and Africa. By ending the story with the triumph of legal abolition, historians risk valorizing the symbol of emancipation at the expense of understanding the labor regimes enforced on the formerly enslaved by the same propertied interests. To capture this powerful truth, Furcy's story should consider what Furcy's and Constance's "freedom" meant in this post-emancipation context.

If the documentary trail and the events of Furcy's life promote his selection as the story's central figure, we nevertheless face another narrative quandary regarding Furcy's point of view. The very limited nature of evidence in Furcy's own voice-a scant eight letters, most of which were probably composed by a professional letter-writer for pay, and the politically fraught nature of the judicial and journalistic evidence of his life in the public eye-leaves Furcy's own perspective, personality and motives largely a matter for conjecture. What prompted Furcy, for example, to pursue his appeal for over a quarter of a century, from the 1817 Bourbon court decision to its overturning by Paris Cour royal in 1843, when he lived the life of a free man under English law? Were Furcy's motivations personal-to be reunited with his family in Ile Bourbon-or political-to champion the right of movement or to contribute to the French anti-slavery movement? 

Whether told as microhistory or scholarly biography, Furcy's story must be embedded within a wider historical narrative chronicling French policy and regulation of citizenship, race, slavery, abolition and regime change (elements of interpretation that would probably be omitted in a work of fiction, or simplified as background and dialogue in less detail). Is Furcy a forgotten non-white hero of France's antislavery movement (as I originally cast him in several conference papers)? Or did his narrow-if diligent-focus on achieving individual personal freedom make Furcy a stooge of the liberal July monarchy, which sought to perpetuate colonial slavery as long as possible through policies of amelioration and "exceptionalism"? Indeed, the Free Soil principle, upon which Furcy's freedom was finally legitimated by France's highest court of appeal, in practice could liberate only a small fraction of those held in slavery in Ile Bourbon. Like manumission, Free Soil may have functioned as an escape valve, allowing France to perpetuate the institution of slavery "over there" by freeing only a select handful of "meritorious" individuals whose masters assisted in their reaching the European metropole.

It may be significant that several exemplary life histories of enslaved people have focused on the stories of entire families or communities, rather than the limited stories of particular individuals. (I'm thinking here of Gordon-Reed, Scott, and Jones.) Judith M. Brown proposes such "family life histories" to explore the social networks in which people live their lives (Brown, 2009, 591). Such a narrative strategy implicitly foregrounds the interdependence of people and the social ties that help them through adversity, as well as the specific mechanisms in relations of exploitation. It seems to me that the social biography, then, offers an alternative political vision of human experience to the individualism of more conventional biographies.

\section{Invention}

The most obvious difference between formal historical writing (whether biography or microhistory) and fiction is the degree of permitted invention. Historians are tethered to "facts"-what is known via evidence, mostly in the form of documents, preferably archival-and reasoned speculation: what can be hypothesized on the basis of similar historical situations, or theory, or what passes as "common sense." To be sure, speculation (most especially when inexplicit or unselfconscious) opens professional historians to charges of bias or fabrication. But, of course-after researching evidencefilling the gaps between "facts" is the very essence of historical narrative-building, connecting the dots to develop a plausible story and explanation for those events. Indeed, I would argue that the social biography approach has tremendous capacity to prompt new historical questions that can spur more traditional modes of social historical inquiry. ${ }^{29}$

In the novel, L'affaire Furcy, the author Aïssouai tethers his story fairly closely to the available documentation with a few exceptions, some elaborate, most minor. To cite a few examples: the opening two chapters imagine Furcy witnessing the capture and execution of a maroon and a conversation between the unscrupulous master, Joseph Lory, and his cigar-smoking companion Auguste Billiard, the details, if not the sheer facts, of which clearly arise from the author's imagination (13-20); ${ }^{30}$ although available documentation suggests that Furcy's mother was illiterate and died in 1812, the novel

Transatlantica, 2 | 2012 
allows her to live until 1817 and to piece together the necessary documentation for Furcy's initial lawsuit for freedom (36-38); Furcy appears twice clutching the Droits de l'homme in his left hand $(78 ; 112)$. Such inaccuracies are the novelist's prerogative and allow him to develop the characters, plot and theme according to his own vision. ${ }^{31}$

Historians are not permitted these flights of fancy; indeed we are required to cite sources for every detail of the narrative (multiplying the hours, if not the years of the writing process). Yet, as Jean Hébrard (Hébrard, 2003) and Michael Zeuske (Zeuske, 2011) have so tellingly argued, the very existence of historical evidence-the forces and personnel that caused pen to be put to paper, thereby creating the evidence on which we base our arguments-is embedded in the power structures of the periods we wish to study. From the slave ship manifestos to the parish registers, to police and court records, institutions of domination and regulation both produced the "evidence" on which historians' accounts of enslaved people rely and selectively preserved these records to make them available to researchers today. Indeed, the very naming of people in the historical record is subject to the power of masters, clerks, priests, notaries and administrators. Few historical "facts" are untainted by these systems of producing and retaining knowledge/power.

Perhaps this is one reason why fiction is such an appealing mode for evoking the perspectives of the past. Many writers from the Antilles have embraced historical fiction as a powerful way to connect present inequalities to the injustices of the past. For, a character or event in a novel does not need to be "demonstrable," buttressed by the scaffolding of scholarly citation to certifiable scholarly evidence, only "plausible"to the reader's sense of emotional truth and, if the aim is higher, to scrutiny by historically minded critics.

Moreover, fiction's license to invent allows the writer and reader to imagine the interior perspective of a character, to fill in the subjectivity of people whose beliefs, motives and desires are all but absent in the "documentable" past. This is what makes fiction potentially very powerful in the service of a politically-oriented historical narrative. A novel can imagine-and allow a reader to imagine-oneself in the place of people of the past, allowing for empathy and solidarity, when the historical trail of evidence has run cold.

\section{Point of View}

Professional historiography, including microhistory, pushes the historian to the front of the story: "this is my interpretation, my argument." It is the necessary product of contemporary academic institutions and culture. Professional standing is to a great degree determined by originality of interpretation, the founding intellectual schools of thought, influence over peers and a subsequent generation of scholarship. In the United States, undergraduates are taught to omit the "I," in academic historiography, except when articulating their thesis: "I will argue that...."

The novel, by contrast, typically relies on a fundamental break between the authorial "I" and that of the narrator. Sometimes, an author will adopt the point of view of one of the characters, even to the point of creating a fictional "I" to narrate the story. This is the case in Aïssaoui's novel (11-12; 21-22; 97-99; 134-35; 152-54); the fictive narrator interrupts the novel periodically to muse upon the research and writing of the book, much like Patrick Chamoiseau's alter-ego, Cham-Oiseau in the novel Texaco (1992). 
Though the novelist's narrative style is often integral to the enjoyment of fiction, the author's voice is never completely identical with the fictive "I". The author, as a living, breathing being, embodied in the "I" of narration, is eclipsed by the "narrative voice," which adopts a fictive point of view on the story's characters.

The popular biography is a kind of hybrid between "straight" history and historical fiction. To satisfy historians, a biography must include the evidentiary apparatus of citation and interpretive sophistication with regard to handling of gaps in sources. But to satisfy a general audience, the biography must "tell a good story," bury some of this interpretive architecture in notes, or eschew it altogether. As in fiction, authorial style is the hallmark of good writing, but as in professional historiography, the pronoun "I" rarely appears in the biography, except in the preface or introduction.

\section{Which Stories? Which Audience?}

Thus far, I have been considering the politics of historical narration in fairly close focus. By way of conclusion, I want to step back to what filmmakers would call the "wide shot." Which stories should we tell and for whom do we write?

Historians today share the objectivists' aim of telling the truth about the past, yet following the postmodern turn, we also doubt the capacity of any historical narrative to be fully objective, if only because, through the selection of topic and argument, our stories are necessarily limited. Therefore, from the very outset, our histories are embedded in relations of power by virtue of the topics that we select to research, not only the ways that we tell those stories.

What is the political value of telling the stories of people who lived under the legal regime of slavery? And are there implicit dangers therein? Furcy's story has the capacity to teach us many things: about the particular history of France's relationship to slavery and its peculiar (to present-day Americans) blindness to the workings of both institutional and quotidian racism; about the determination of some individuals to claim a measure of dignity within such a system; about the use of lawsuits to stimulate public opinion and bring about legal reform, but also about the inherently conservative nature of written law and how mechanisms of exceptionalism (like the Free Soil principle) can paradoxically work to reinforce slavery itself by legitimating its continued existence outside the boundaries of the "free" nation state. Many of these elements have corollaries in contemporary society but may be easier to see at a historical distance.

Narrating the life stories of individuals and networks of people who lived under-and resisted-enslavement can therefore inspire readers to seek justice through engagement and empathy across differences (cultural, temporal, social). However, we, as writers, need to be careful. Without sufficient self-reflection, there is a danger that in revisiting the period of slavery and slaves' stories, we may inadvertently re-inscribe presentist stereotypes and perspectives or, worse, unwittingly reinforce the inequalities left to us by those who wielded the quill. We need to read our sources "against the grain" to reveal the omissions, distortions and invisible violence inherent in power differential of those whose privileges allowed them to create and preserve the historical record for posterity. For whom do we write? 


\section{Appendix: Three Versions of a Scene from Furcy's Story}

\section{Microhistory}

On04 October 1808 Madame Routier died at the age of seventy, a ripe old age for a colonial widow. ${ }^{32}$ We have two different eye-witness accounts of this time, Constance's petition, originating almost a decade later, in 1817, in the midst of Furcy's dispute with Joseph Lory, ${ }^{33}$ and a lengthy document titled "Notes de Furcy," revised in the same handwriting to read, "Notes écrits sans la dictée de Furcy [Notes written without the dictation by Furcy]." ${ }^{34}$ Both documents tell the events from the point of view of Constance and Furcy and portray Lory as an unscrupulous cheat. The second document is at once very important and highly ambiguous. The revised title suggests that the note-taker wishes to distance Furcy from the testimony it contains, yet some of its details could only have been reported by Furcy himself (including dialogue between himself and Joseph Lory). What is more, "Notes de Furcy" narrates events from 1808 until 1829, which suggests that more than two decades had transpired since Madame Routier's death. Both documents contain demonstrable inaccuracies, introduced by faulty memory or wishful thinking over the intervening years, and the accounts differ in some of the particulars, but the overall picture is fairly consistent: Lory managed to trick Madeleine into signing papers that cheated her out of nineteen years' back wages and reneged on a promise to free Furcy.

\section{Biography}

In5August $1809,{ }^{35}$ Joseph Lory told Furcy to go find his mother "who no longer lived at his house" and to "bring her to the home of M. Michault d'Emmery, the notary of his family." ${ }^{36}$ However, when the Madeleine arrived at the notary's office, she was informed that she needed a witness. She went out to get M. Hirau (presumably someone she trusted), ${ }^{37}$ but when she returned to the notary's office, she was told that a M. Lison would serve as the witness. ${ }^{38}$ Lory said that he would prepare an act whereby Furcy would be freed within six months or a year and he extracted from her a fee of 4 ecus, which he said was required when a slave was manumitted. Instead, Madeleine, unable to read the document, unknowingly signed a receipt for one year of back wages, renouncing the remainder of her back wages. The paper she signed did not mention the condition of freeing her son Furcy ${ }^{39}$; rather it assigned Furcy as Lory's slave until his master's death. ${ }^{40}$

\section{Fiction}

Furecy was clearing away the morning's demitasses, the acrid sweet smell of coffee, sweat and Lory's tobacco lingering in the air.

"Leave those for now," Lory waved his hand. "I want you to go get your mother and bring her to Michault's."

Furcy looked up, startled, but knew better than to question Lory. "Oui, monsieur," he murmured, moving toward the door. A flutter rose in his heart. Was this to be the day? But surely not. Lory had been smiling. He must have something up his sleeve... 
Madeleine stood for a moment outside the thick, finely beveled door. This was to be the moment of truth! All her years of labor and loyalty to the Routier family would now reap her just reward. Lory's greed had finally overcome his need for personal domination. He knew that her back wages were worth at least three times the purchase price of a skilled man like her son. Madeleine knew that in the end Lory would see reason and accept her deal.

Drawing up to her full five feet of height, Madeleine set her chin. She would not let them intimidate her. She knocked.

Antoine, the notary's servant let her in and down a dark hallway into a parlor lined with books and files. Thousands-no, millions-of sheets of paper surrounded the room! Michault, that fat, balding, bespectacled man sat behind an enormous desk, piled high with folders and more loose sheets of paper. Each sheet was covered with a spidery scrawl, looping infinitely from edge to edge in monotonous waves of ink. How did these people make sense of such ciphers, the endless scratches and loops? Spoken words were so much clearer-even when there were hidden meanings and intentions, you could gather these from the speaker's breath, the tightness at the lips, a hand scratching the nose, the set of the eyes. Madeleine knew how to read people and was determined to finalize this deal with dignity. Furcy's future depended on her.

Michault watched Madeleine's eyes take in the room. "Eh bien," he began. "You are here to do some business. But first we must have a witness."

A witness, yes! Madeleine thought of Robert Hirau, the shopkeeper, two doors down. He could read these papers and had even advanced her small items, a lemon, a needle, in the past, which she had always paid off in time. "Excusez-moi monsieur." She fairly fled out the door.

But when she returned, breathless, a few minutes later with Robert, the room was crowded with new bodies: Michault, but also Joseph Lory and that pale, watery man Lison. "You may go, Hirau," said Lory, smiling but with an unspoken command. "We are ready."

\section{BIBLIOGRAPHIE}

“AHR Roundtable: Historians and Biography," American Historical Review, 114:3, June 2009, 573-661.

BILLIARD, Auguste and Jean-Pierre BACHASSON MONTALIVET, Voyage aux colonies orientales: lettres écrites à M. le comte de Montalivet, ancien ministre de l'Intérieur, pendant les années 1817 à 1820, Sainte Clotilde, La Réunion, ARS Terres créoles, 1990.

BISSETTE, Cyrille, "Affaire Furcy: les esclaves qui touchent le sol de la France sont libre," L'abolitioniste français, 1, 1844, 58.

BLIGHT, David W., A Slave No More: Two Men Who Escaped to Freedom: Including Their Own Narratives of Emancipation, Orlando, Harcourt, 2007. 
BROWN, Judith M., “'Life Histories' and the History of Modern South Asia,” The American Historical Review, 114:3, June 2009, 587-95.

CARRETTA, Vincent, Equiano, the African: Biography of a Self-Made Man, Athens, University of Georgia Press, 2005.

CHAMOISEAU, Patrick, Texaco, Paris, Gallimard, 1992.

CHAULEAU, Liliane, Dans les îles du vent: la Martinique (XVIIe-XIXe siècle), Paris, L'Harmattan, 1993. Contextes historiques et géographiques, Exposition: Musée Léon, accessed 22 August 2011, http:// www.college-edmondalbius.re/cdi1/documents/reunion/esclavage.pdf.

COOPER, Fredrick, Thomas C. HOLT, and Rebecca J. SCOTT, Beyond Slavery: Explorations of Race, Labor, and Citizenship in Postemancipation Societies, Chapel Hill, University of North Carolina Press, 2000.

CRAIS, Clifton and Pamela SCULLY, Sara Baartman and the Hottentot Venus: A Ghost Story and a Biography, Princeton and Oxford, Princeton University Press, 2009.

DAVIS, Natalie Zemon, The Return of Martin Guerre, Cambridge, Harvard University Press, 1983.

DAVIS, Natlaie Zemon, Slaves on Screen: Film and Historical Vision, Cambridge, Harvard University Press, 2000.

FALLOPE, Josette, "Esclaves et citoyens: les noirs à La Guadeloupe au XIX siècle dans les processus de résistance et d'integration, 1802-1910," Thèse de doctorat, Université de Paris X-Nanterre, 1989.

FONER, Eric, Free Soil, Free Labor, Free Men: The Ideology of the Republican Party before the Civil War, New York and Oxford, Oxford University Press, 1970.

FUMA, Sudel, ed., Mémoire orale et esclavage dans les îles du Sud-Ouest de l'océan Indien: silences, oublis, reconnaissance, Saint-Denis, Université de la Réunion, 2005.

Gazette des tribunaux, 13 août $1835, n^{\circ} 3114$.

GERBEAU, Herbert, “L'Océan Indien n'est pas l'Atlantique: La traite illégale à Bourbon au XIXe siècle," Outre-Mers, 336-337, December 2002, 9-13.

GINZBURG, Carlo, Il formaggio e I vermi (1976), The Cheese and the Worms: The Cheese and the Worms: The Cosmos of a Sixteenth Century Miller, Baltimore, Johns Hopkins University Press, 1980.

GORDON-REED, Annette, The Hemingses of Monticello: An American Family, New York and London, W.W. Norton, 2008.

GRENDI, Eduardo, “Micro-analisi e storia sociale,” Quaderni storici, n³5, 1977, 506-20.

HAMILTON, Nigel, Biography: A History, Cambridge and London, Harvard University Press, 2007.

HÉBRARD, Jean, "Esclavage et dénomination: Imposition et appropriation d'un nom chez les esclaves de la Bahia au XIXe siècle," Cahiers du Brésil Contemporain, 53/54, 2003, 31-92.

HEUER, Jennifer, "The one drop rule in reverse? Interracial marriages in Napoleonic and Restoration France," Law and History Review, 27:3, Fall 2009, 515-48.

JENNINGS, Lawrence C., “Cyrille Bisette: Radical Black French Abolitionist,” French History, 9:1, 1995, 48-66.

JONES Martha S., Riding the Atlantic World Circuit: One Household's Journey through the Law of Slavery and Freedom, in progress. 
KENNEDY, Melvin D., "The Bissette Affair and the French Colonial Question," The Journal of Negro History, 45: 1, January 1960, 1-10.

LAUDEDALE GRAHAM, Sandra, Caetana Says No: Women's Stories from a Brazilian Slave Society, New Approaches to the Americas, New York, Cambridge University Press, 2002.

LEROY LADURIE, Emanuel, Montaillou, village occitan (1975), Montaillou, translated by Barbara Bray, New York, Vintage Books, 1979.

LEROY LADURIE, Emanuel, Le Carnaval de Romans, 1579-1580 (1979), Carnival in Romans, translated by Mary Feeney, New York, George Braziller, 1979.

LOVEJOY, Paul E., “'Freedom Narratives' of Transatlantic Slavery,” Slavery \& Abolition, 32:1, March 2011, 91-107.

MANN, Susan, “Writing Biography in Chinese History,” AHR, 114:3, June 2009, 631-39.

MUIR, Edward and Guido RUGGIERO, eds., Microhistory and the Lost Peoples of Europe (Selections from Quaderni Storici), Baltimore, Johns Hopkins University Press, 1991.

PAME, Stella, Cyrille Bissette : Un martyr de la liberté, Fort de France, Désormeaux, 1999.

PEABODY, Sue, "There Are No Slaves in France": The Political Culture of Race and Slavery in the Ancien Régime, New York and Oxford, Oxford University Press, 1996.

PEABODY, Sue, "Window, Prism and Mirror: A Pedagogy of Historical Fiction in the Historical Classroom," in Approaches to Teaching Claire de Duras's Ourika, Mary Ellen Birkett and Chris Rivers, eds., Approaches to Teaching Series, Joseph Gibaldi, series editor, New York, Modern Language Association of America, 2009, 122-28.

Plaidoyer pour le sieur Furcy indien, demeurant à l'ile de France, appelant, contre les veuve et héritiers Lory, demeurant à l'ile Bourbon, intimés, Paris, Imprimerie de J. Delalaine, 1844.

POPKIN, Jeremy D., History, Historians, and Autobiography, Chicago, University of Chicago Press, 2005.

RICQUEBOURG, Camille L.J., Dictionnaire généalogique des familles de l'isle Bourbon (La Réunion) 1665-1810, Mayenne, Imprimerie de la Manutention, 1983.

SAVAGE, John, "Between Colonial Fact and French Law: Slave Poisoners and the Provostial Court in Restoration-Era Martinique," French Historical Studies, 29:4, Fall 2006, 565-94.

SCHLOSS, Rebecca Hartkopf, Sweet Liberty: The Final Days of Slavery in Martinique, Philadelphia, University of Pennsylvania Press, 2009.

SCOTT, Rebecca J., "Public Rights and Private Commerce: A Nineteenth-Century Public Creole Itinerary," 2005 Sydney W. Mintz Lecture, Current Anthropology, 48:2, April 2007, 237-56.

SCOTT, Rebecca J. and Jean M. HEBRARD, “Servitude, liberté, et citoyenneté dans le monde Atlantique des XVIIIe et XIXe siècles: Rosalie de nation Poulard...," Revue de la société Haïtienne d'histoire et de géographie, 83:234, July-September 2008, 1-52.

SCOTT, Rebecca J. and Jean HÉBRARD, Freedom Papers: An Atlantic Odyssey in the Age of Emancipation, Cambridge, Harvard University Press, 2012.

SERNETT, Milton C., Harriet Tubman: Myth, Memory, and History, Durham, Duke University Press, 2007.

VANDERVELDE, Lea, Mrs. Dred Scott: A Life on Slavery's Frontier, Oxford, Oxford University Press, 2009. 
VERGÈS, François, Monsters and Revolutionaries: Colonial Family Romance and Métissage, Durham and London, Duke University Press, 1999.

WANQUET, Claude, Histoire d'une Révolution, La Réunion 1789-1803, 3 vols., Marseille, Jeanne Laffitte, 1980-1984.

WANQUET, Claude, La France et la première abolition de l'esclavage, 1794-1802: le cas des colonies orientales, Ile de France (Maurice) et la Réunion, Paris, Karthala, 1998.

WHITE, Hayden, Metahistory: The Historical Imagination in Nineteenth-Century Europe, Baltimore and London, Johns Hopkins University Press, 1973.

ZEUSKE, Michael, "The Names of Slavery and Beyond : the Atlantic, the Americas and Cuba" in The End of Slavery in Africa and the Americas, Ulrike Schmeider, Katja Füllberg-Stolberg, and Michael Zeuske, eds., Berlin, Lit. Verlag, 2011, 51-80.

\section{NOTES}

1. Many thanks to Richard Blackett, Pierre Boulle, Catherine Desbarats, Nathalie Dessens, Jean Hébrard, Jane Landers, Jean-Pierre Le Glaunec, Allan Megill, and Rebecca Scott for their readings of earlier versions of this paper and to Vanderbilt University's Robert Penn Warren Center for the Humanities and McGill University's French Atlantic History Group, for the opportunity to present it to students and faculty there.

2. Some of the most important recent works include VanderVelde, Blight, Carretta, and Sernett cited in the bibliography.

3. All the works cited in this paragraph are listed in the bibliography.

4. See the forum, "AHR Roundtable: Historians and Biography."

5. The distinction between popular and scholarly audiences in France is less sharp than in the United States, where the biography is very popular but the genre is typically more celebratory, less critical.

6. I propose the Calvinist salvation myth as the fundamental plotline of abolitionist slave narratives in my forthcoming review of Christopher L. Miller's The French Atlantic Triangle: Literature and Culture of the Slave Trade for Nieuwe West-Indische Gids, 84:1 \& 2, 2010.

7. This is the formulation of Eduardo Grendi (Grendi, 1977, esp. 512), cited frequently in the works of Carlo Ginzburg, Jacques Revel, and others.

8. See, in particular, Ginzburg, 1980; Leroy Ladurie, 1975 and 1979; Davis, 1983.

9. Mohammed Aïssouai won the Prix Renaudot for his book entitled L'affaire de l'esclave Furcy (Paris, Gallimard, 2010) in 2010 for outstanding fiction. Hassane Kassi Kouyaté's L'Affaire de l'esclave Furcy was produced at Le Tarmac theatre 20 November to 15 December 2012 and at Le Sechoir and Théâtre de Champ Fleuri in La Réunion in April 2013. Examples of my early experiments in a fictive voice can be found in the appendix to this paper.

10. I discuss strategies for using this distortion as an educator in Peabody, 2009, 122-28.

11. The historiography is too vast to cite comprehensively here but includes researchers in Réunion (Prosper Eve, Claude Wanquet, Sudel Fuma, Gubert Herbeau, Jean-François Geraud), and the United States, Canada, and Britain (Edward Alpers, Richard Allen, Gwyn Campbell, Meagan Vaughan, Marina Carter, Anthony J. Barker, Indira Chatterjee).

12. Since the sixteenth century, French law held that any slave who set foot on French soil became free. A series of eighteenth-century laws effectively suspended this principle, including the Declaration of December 23, 1738, which-if enforced by the courts-would have had Madeleine confiscated as the king's property and returned to the colonies as a slave (Peabody, 1996, 3, 4-6). I originally referred to this maxim as the "freedom principle," but in analyzing it 
more comparatively, with particular emphasis to the crossing of national borders, I have begun to use the term Free Soil principle, which should, of course, be distinguished from the antebellum U.S. political party, the Free Soil Party, see Foner, 1970, 1 and passim.

13. The sale of slaves was forbidden in metropolitan France.

14. Marie Charlotte would only live until the age of five, her cause of death unknown. Strangely, in contrast to her fertile and prolific mother (seven children) and older brothers, Augustin (eight children by two successive wives) and Cyrille (nine children), Eugénie did not bear any more children to Joseph Lory until her daughter Marie Charlette [sic] Augustine Euphémie a decade later in 1804.

15. In one case, however, more liberal forces sought to mitigate the prosecution of a group of accused slaves.

16. For more details, see Hartkopf Schloss, 2009; Heuer, 2009; 95 pars. 22 Sep. 2009; Savage, 2006.

17. The colony resumed its former name, Ile Bourbon, when the English occupied the island in 1810. It would retain this name until 1848, when it resumed its current name, La Réunion.

18. "Mr [Jacques Sully] Brunet par son extraction se rattachant à la classe des gens de couleur puisque sa trisaïeule était une femme Madégasse, " in Contextes historiques et géographiques, Exposition: Musée Léon, 23-24, accessed 22 August 2011, http://www.college-edmondalbius.re/ cdi1/documents/reunion/esclavage.pdf.

19. "Je suis né Colon Français et je suis fils d'un Français de naissance," Letter from Furcy, Port Louis, Ile Maurice, to Louis Gilbert Boucher, place unknown, 15 May 1826, Archives Départementales de la Réunion, 1Jp2007-1, no. 71.

20. Bissette and 46 men of mixed race were expelled from Martinique in 1823 for advancing antislavery and anti-racist literature. Their appeal became a cause célèbre. Bissette would go on to found two antislavery journals, the Revue des colonies and L'abolitioniste française, the latter of which would discuss Furcy's legal appeal in its inaugural 1844 issue (Bissette, 1844, 58). See also Kennedy, 1960, 1-10; Fallope, 1989, 280-81 ; Chauleau, 1993, 266 ; Pâme, 1999 ; Jennings,1995, 48-66 ; Schloss, 2009, 99-101, 121. On the political consciousness of the Canadian métis in the early nineteenth century, see Jacqueline Peterson, "Rethinking Métis Ethnogenesis in the Great Lakes Region," paper presented at the French Colonial Historical Society meeting, Saint Denis, France, June 2010.

21. "Probably" because it seems likely that Furcy's appeal before the Cour de Cassation in August 1835, covered in the Paris press, drew official attention to the status of Free Soil in the metropole, prompting the April 1836 legislation. Gazette des tribunaux, 1835, 1; Plaidoyer pour le sieur Furcy indien, 1844, 8.

22. Sheer access to some of these documents has proven challenging, as they have not yet been made available to all researchers. Herbert Gerbeau notes that certain archival collectionsregarding marronage, slave revolt, miscegenation-were deliberately destroyed or removed from public access (Gerbeau, 2002, 9-13). Gerbeau concludes with an appeal to find documents in "archives privées," which might fill these silences with testimony but access to these is also restricted.

23. However, there is also one signed with an X. It is hard to tell whether Furcy employed an amanuensis or drafted and signed most of the letters himself.

24. On historical silences and the experiences of slavery, see Fuma, 2005.

25. See Hamilton, 2007, 6-59. Hamilton's overview, limited to the Western tradition, is generally most insightful in his discussion of twentieth-century developments. Susan Mann suggests that the biographical tradition is also indigenous to Chinese historiography, especially in the celebration of exemplary individuals (Mann, 2009, 631-39).

26. Muir, "Introduction," in Muir and Ruggiero, eds., 1991, viii-xiv.

27. Witness, for example, Toni Morrison's Beloved. See also, Davis, 2000. 
28. This is the style adopted, I imagine quite self-consciously, by Rebecca Scott and Jean Hébrard in several of their recent essays. For example Scott, 2007, 237-56; Scott and Hébrard, 2008,1-52 ; Another, perhaps less successful, example, to my mind, is found in Graham, 2002. The narrative of Caetana often bogs down in what seems to be extraneous information about secondary "characters," included, one suspects, primarily because it was simply more available.

29. For example, the need to contextualize Madeleine's experience as a child slave in India and Constance's life as a free woman of color in Ile Bourbon have prompted me to investigate serial receipts and census records with an eye to reconstituting the average age of slaves or patterns of slave-owning by free people of color.

30. Billiard was an aristocratic voyager who circulated in elite circles of Ile Bourbon from 1817 to 1820 and left a published collection of letters, as well as several colonialist projects for the Ministry of the Marine, but there is no indication that he visited Joseph Lory (Billiard and Bachasson Montalivet, 1990).

31. Though, it must also be admitted, that the last invention-the insertion of the droits de l'homme-may be received as offensive to present day readers in Réunion who resist metropolitan paternalism. On a feminist analysis of Réunion's anti-colonialism, see Vergès, 1999.

32. L.J. Camille Ricquebourg, Dictionnaire généalogique des familles de l'isle Bourbon (La Réunion) 1665-1810, Mayenne, Imprimérie de la Manutention, 1983, 1, 691. Furcy would later mistakenly suggest that this occurred in 1810 ("Notes [écrits sans la dictée] de Furcy," n.d., A.D. Réunion, 1 Jp 2007/1, doc. 51).

33. There are two nearly identical versions of Constance's petition: Copy "Mémoire de Constance en faveur de Furcy," 9 November 1817, (A.D. Réunion, 1Jp2007-1, No. 3) and "Extrait d'un Mémoire déposé au greffe de la Cour Royale de l'Ile de Bourbon le trois Décembre 1817 par Mr. Le Procureur général pour servir s'il y a lieu, à intenter toute procédure criminelle ou correctionnelle," (A.D. Réunion, 1Jp2007-1, No. 36). The latter is more complete, with some new marginalia, and in a hand that is much easier to read; I quote from it here.

34. "Notes écrits [sans la dictée] de Furcy," n.d., (A.D. Réunion, 1 Jp 2007/1, doc. 51).

35. "Extrait d'une Mémoire déposé au greffe de la Cour Royale de l'ile de Bourbon le trois Décembre 1817 par Mr. Le Procureur général pour servir s'il y a lieu, a intenter toute procédure criminelle ou correctionnelle," (A.D. Réunion, 1Jp2007-1, No. 36).

36. "Notes [écrits sans la dictée] de Furcy," n.d., (A.D. Réunion, 1 Jp 2007/1, doc. 51).

37. There is no one by this name in the Dictionnaire Généalogique. Perhaps this was a free man of color.

38. "Notes [écrits sans la dictée] de Furcy," n.d., (A.D. Réunion, 1 Jp 2007/1, doc. 51). Lison's name does not appear in the Dictionnaire généalogique.

39. “Extrait d'une Mémoire déposé au greffe de la Cour Royale de l'ile de Bourbon le trois Décembre 1817 par Mr. Le Procureur général pour servir s'il y a lieu, a intenter toute procédure criminelle ou correctionnelle," (A.D. Réunion, 1Jp2007-1, No. 36).

40. “Notes [écrits sans la dictée] de Furcy," (n.d.), (A.D. Réunion, 1 Jp 2007/1, doc. 51).

\section{AUTEUR}

\section{SUE PEABODY}

Washington State University - Vancouver 